\title{
SPAWNING PERIODICITY OF SEA URCHINS AT SETO -I. MESPILIA GLOBULUS-
}

$\operatorname{AUTHOR}(S)$ :

Kobayashi, Naomasa

\section{CITATION:}

Kobayashi, Naomasa. SPAWNING PERIODICITY OF SEA URCHINS AT SETO -I. MESPILIA GLOBULUS-. PUBLICATIONS OF THE SETO MARINE BIOLOGICAL LABORATORY 1967, 14(5): 403-414

ISSUE DATE:

1967-01-25

URL:

http://hdl.handle.net/2433/175449

RIGHT: 


\title{
SPAWNING PERIODICITY OF SEA URCHINS AT SETO
}

\author{
I. MESPILIA GLOBULUS ${ }^{13}$
}

\author{
NAOMASA KOBAYASHI
}

Biological Laboratory, Dôshisha University, Kyoto

With Plates XII-XIII and 3 Text-figures

A belief that many sea animals inclusive of sea urchins manifest the lunar periodicity in spawning of sexual products has long been held by many workers. However, there are some species of sea urchins in which the spawning rhythm with such periodicity can not be confirmed, and even in some single species there may be discrepancies of opinions, one argues the periodicity and the other denies it. Such previous works will be referred to later in the discussion of the present experiment.

For several years the author has been engaged in cytological works at the Seto Marine Biological Laboratory of the Kyoto University using eggs of Mespilia globulus for the material. The author's experiences seemed to show that there was an evident trend that eggs of enough quality and quantity for the works were obtainable not only in the period of full moon but also in the period of new moon during the breeding season. Tnis seems to suggest that Mespilia globulus spawns twice a month at Seto, respectively at full moon and new moon, or the sexual maturity of the sea urchin is harmonized with the hemi-lunar periodicity. To confirm this phenomenon the athor's research records for successive four years from 1958 to 1961 were re-examined, in which the results of measurements of the gonad volume and histological examinations of the gronad made continuously in 15 days around new moon from July 5 to July 19, 1961, were included. On these data, the spawning periodicity of this sea urchin was discussed.

\section{Material}

Mespilia globulus (LinNé) is an inhabitant of the south west coasts of the North Pacific and in Japan the locality ranges northward to the Bôso peninsula. In the breeding season from July to September, this sea urchin is not rare in shallow water in rocky shore at Seto but disappears from there in other seasons. The specimens used for examinations were restricted to fully grown individuals with a diameter from

1) Contributions from the Seto Marine Biological Laboratory, No. 463.

Publ. Seto Mar. Biol. Lab., XIV (5), 403-414, 1967. (Article 26) 
2.0 to $2.5 \mathrm{~cm}$. Fully mature individuals were highly sensitive to stimulations and easily discharge their genital products, so that specimens were collected at the low tide of the days when they were used. When the collecting of specimens was disturbed by rough water, observations were made on the specimens kept in the laboratory aquarium. In most cases, the rough water ceased in one or two days.

\section{Examination of sexual products obtained by forced spawning}

During the breeding season the amount of eggs and sperms obtained by the current $\mathrm{KCl}$ method fluctuated through the specimens successively sampled. Although the amount of these sexual products seemed to reflect the grade of maturity of gonads, not only fully ripe ones but unripe or over-ripe ones were shed by forced spawning. Therefore, the maturity could not be estimated directly from the quantity of shed products. Eggs and sperms obtained were subjected to microscopical examination. As it was difficult to distinguish morphologically unripe and over-ripe sperms from healthy ones or over-ripe eggs from mature ones, the mobility and fertility of sperms in sea water, and the mode of cleavage of eggs after fertilization were examined. Taking the results of these examinations into account, the maturity of gonads was divided into five arbitrary classes graded from +++ to - according to the amount of fully matured sexual products as shown in the caption of Text-fig. 1 .

More than 30 specimens of both sexes were examined in respective days and the daily mean maturity was plotted on the graph (Text-fig. 1). As will be shown later this arbitrary classification roughly correlated with that based on the volume of gonads. The observation was continued for 30 days from July 14 to August 12 in 1958,35 days from July 10 to August 13 in 1959, 49 days from July 18 to September 4 in 1960, 94 days from June 20 to Septermber 20 in 1961. The smooth curves in Text-fig. 1 indicate the fluctuations in the maturity of gonads in these periods. It is noticed that the undulating curves superficially approximates to the sine curve, the maxima of the curves being attained at the time of both new and full moon indictaed in the figure respectively by solid and open circle. Thus, the maturity of gonads has a rhythm harmonizing with the hemi-lunar periodicity.

There were some disturbances in the rhythm. In July 1961 full moon was on the 28th, where the maturation curve was to be at the maximum as shown by the curve of broken line in Text-fig. 1. However, the water was rough on the 25 th and the maximum was achieved on that day. The spawning seemed to be hastened by rough water. But on the other hand, the grade of maturation at the last minimum was significantly higher than usual. Then, it was suggested, that the sexual products of the gonads were not discharged thoroughly at that minimum and thus the gonads became full a few days before the full moon of the 28th. This might be the cause of the precocious spawning. Another point to be noted was the slight drop of the maturation rate after that precocious spawning. The curve reached the next maximum on the next new moon, i.e. the 1 lth of August; the interval between the two 


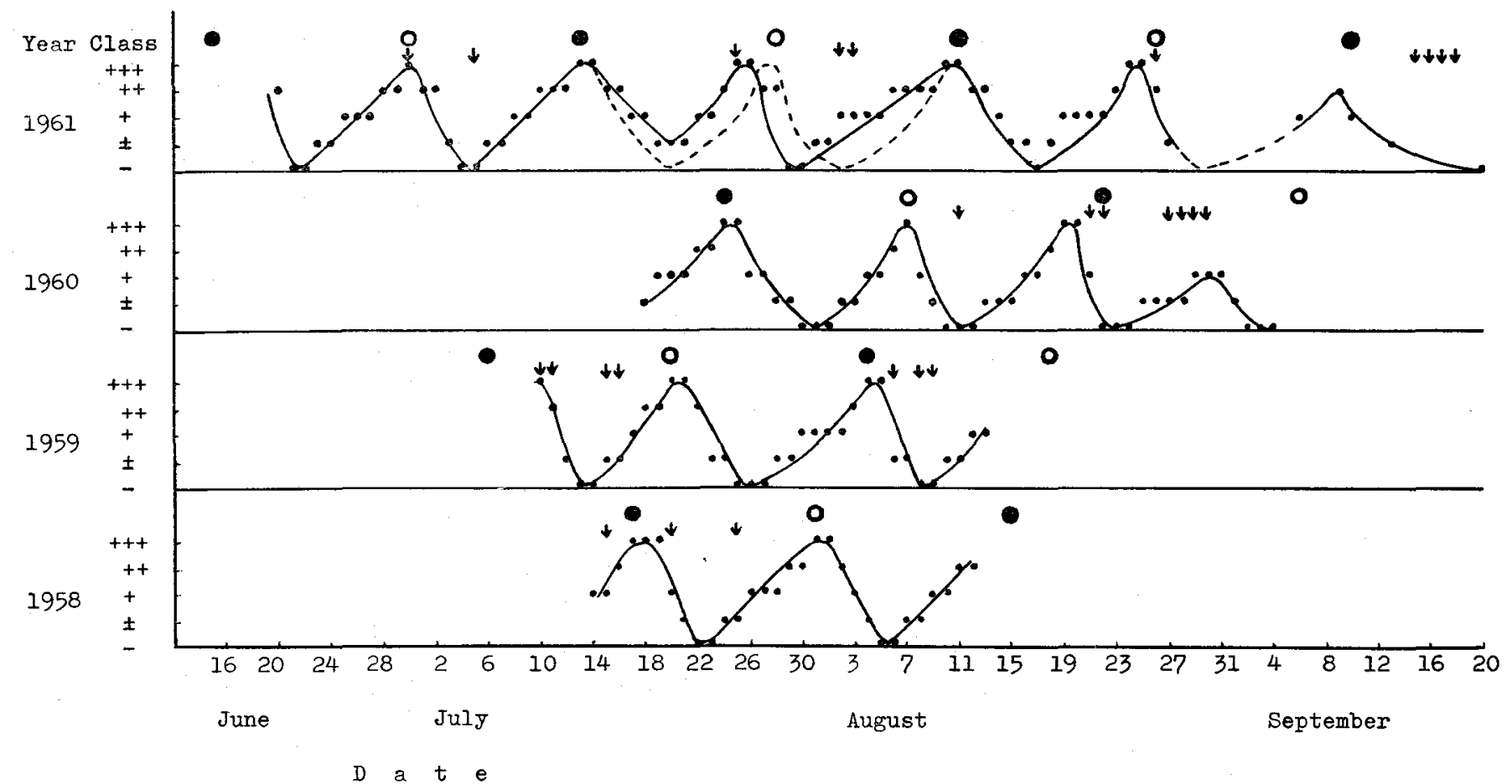

Text-fig. 1. Curves illustrating successive changes of the maturation grade of the gonad in Mespilia globulus at Seto.

$\bigcirc$ : full moon, 0 : new moon, $\cdots$ : expected standard curve, $\downarrow$ : rough water.

For signs of maturation grades or classes see Table 1 . 
successive maxima was prolonged for a few days. Thus, the intrinsic phase of the maturation rhythm was restored. Another example was found in late August of 1960, when the curve reached the maximum on the 30th, about a week before the full moon. In this case the rough water lasted for four days and the maturity of gonads remained at much lower level than usual. It was not uncommon that the maturation curve declined rather sharply after the maximum when the water was rough, but the curve was not affected by rough water when the gonads were empty or remained at a very low level of the maturation grade.

\section{Volume change of gonad}

In the foregoing experiments the grade of sexual maturity was classified into five according to arbitrary qualification of sexual products obtained by forced spawning. To confirm the propriety of this classification successive changes of the gonad volume were examined through a certain cycle of the maturation periodicity. There have been two ways of laying down the grade of gonadal maturation used in previous works; one based on the ratio of the gonadal volume to the test volume (Mooer 1934, Fujr 1960, Moore et al. 1963, Lewis 1966) and the other on the maturation index according to the histological classification and the frequency of individuals belonging to respective classes (Yoshida 1952). In the present experiments, the specimens were restricted to full mature individuals having a test diameter from 2.0 to $2.5 \mathrm{~cm}$ and the volume of gonad was measured daily. The measurement was continued for 15 days around new moon from the 5 th to the 19th of July in 1961, new moon being on the 13th of July and full moon on the 30th of June and on the 28th of July.

The results of the experiments are illustrated in Text-fig. 2. As shown in 'Textfig. 1 , the maturation curve attained the minimum on the 5 th and the maximum on the 13th. In the present experiment the mean volume of ovary and testis was lowest on the $5 \mathrm{th}$, respectively. It was $0.14 \mathrm{cc}$ in female and $0.23 \mathrm{cc}$ in male. The volume of the gonad increased with day and attained the maximum on the 13th in female and on the 12 th in male. The gradient was more prominent in female than in male and at the maximum the mean volume of gonads was $0.61 \mathrm{cc}$ in female and $0.40 \mathrm{cc}$ in male. After attaining the maximum the volume of gonads decreased in both sexes and on the 19th dropped to $0.24 \mathrm{cc}$ and $0.27 \mathrm{cc}$ in femele and male, respectively. The results of those observations exactly conformed to the maturation curve shown in Text-fig. 1. Therefore, the arbitrary classes of the maturation grade of gonads is directly related with the volume changes of gonads. In the present observations the gonads were sorted into five classes according to differences in the volume (Table 1). The classification standard was not same in both sexes, because the minimum and maximum volume of ovary differed remarkably from those of testis. Changes in the percent frequency of individuals of respective maturation classes were plotted in Text-fig. 3. In the figure the frequency of spent individuals (-) is well contrasted with the up and down of fully mature and mature individuals, and it is learned that 


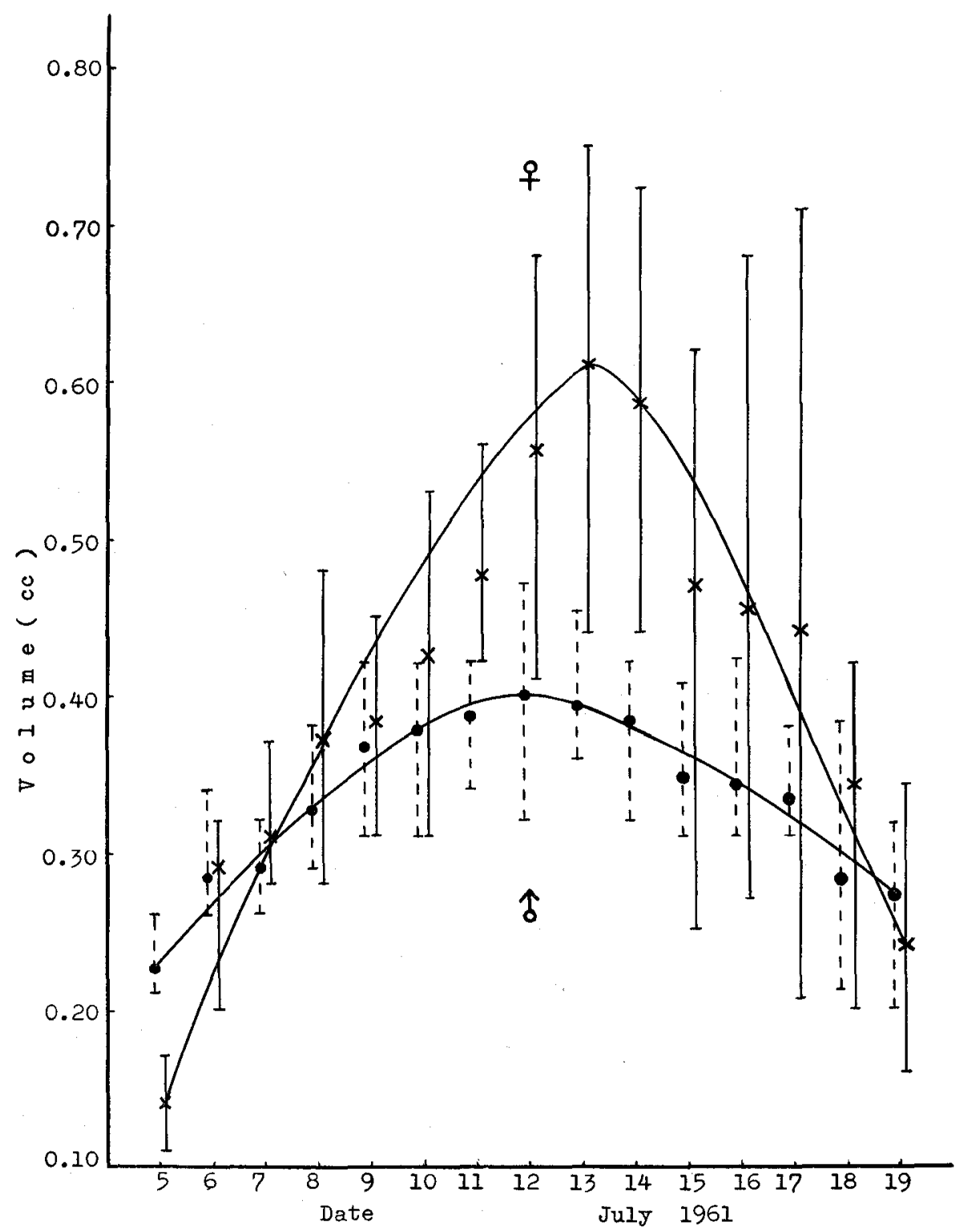

Text-fig. 2. Changes of the gonad volume in both sexes though 15 days from July 5 to July 19 , 1961 , with the new moon on the 13th. Vertical lines indicate each the range of individual variations.

: mean for males, $x$ : mean for females. 
Table 1. Classification of the maturation grade.

\begin{tabular}{c|c|c|c}
\hline \multirow{2}{*}{ Class } & \multicolumn{2}{|c|}{ Volume in average (cc) } & \multirow{2}{*}{ State } \\
\cline { 2 - 4 } & Ovary & Testis & \\
\hline- & 0.14 & 0.23 & wholly spent \\
\pm & $0.25-0.31$ & $0.27-0.29$ & spent \\
+ & $0.35-0.39$ & $0.29-0.34$ & ripening \\
++ & $0.43-0.56$ & $0.34-0.38$ & mature \\
+++ & $0.59-0.61$ & $0.38-0.40$ & fully mature \\
\hline
\end{tabular}

the spent does not appear just after the maximum but does a few days after in both sexes. It is suggested that mature individuals will not become spent immediately by spawning at a time at least under the natural conditions.

\section{Histological changes of the gonad}

Together with the volumetric works the histological examinations of the gonad were carried out on the specimens extracted from the same sample. Gonads were fixed in Bouin's solution, sectioned in paraffin and stained with HeIdenhain's ironhaematoxylin. Tennent and ITo (1941) presented detailed cytological informations on the oogenesis of Mespilia. FuJI (1960) described the developmental processes of gonads in Strongyrocentrotus nudus and S. intermedius and categorized five stages by histological and anatomical examinations. In Diadema, Fox (1924 a) classified the processes of maturation into five stages, and Yoshida (1952) defined nine stages. All these points were referred to in the present observations.

On July 5. The gonads in most of specimens were wholly empty and in the state of the class designated by - in Table 1. The ovary (Plate XII, Fig. 1) consisted of loosely packed acini of small diameter and the interspace among acini was rather wide. The acinus wall was thick and the germinal epithelium was thin. In the lumen of acinus there were deeply stained basophile granules of large sizes scattering along the germinal epithelium. Neither mature ovum nor oocyte was found in the lumen. Oogonia with round nucleus dispersed in the epithelium. In the testis, lobules were not empty, but contained a small amount of granulated substances in the lumen. The germinal epithelium was rather thin and small masses of spermatogonia not so densely packed together were found along the wall of tubule. This stage of gonads seemed to correspond to the "Stage 1" in Diadema (YoshidA, Ioc. cit.) and to the "Stage I" of the recovery spent in Strongyrocentrotus (FuJI, loc. cit.), though the features of gonads described above were not identical with those found in these sea urchins in detail.

On July 7. Gonads were in the class shown by \pm in Table 1. Most remarkable of the ovary in this stage was a sudden increase of acinus diameter and an appearance of occyte in the germinal epithelium (Plate XII, Fig. 2). Oocytes of varioussizes scattered mostly salong the acinus wall, but some in the lumen. The basophile 


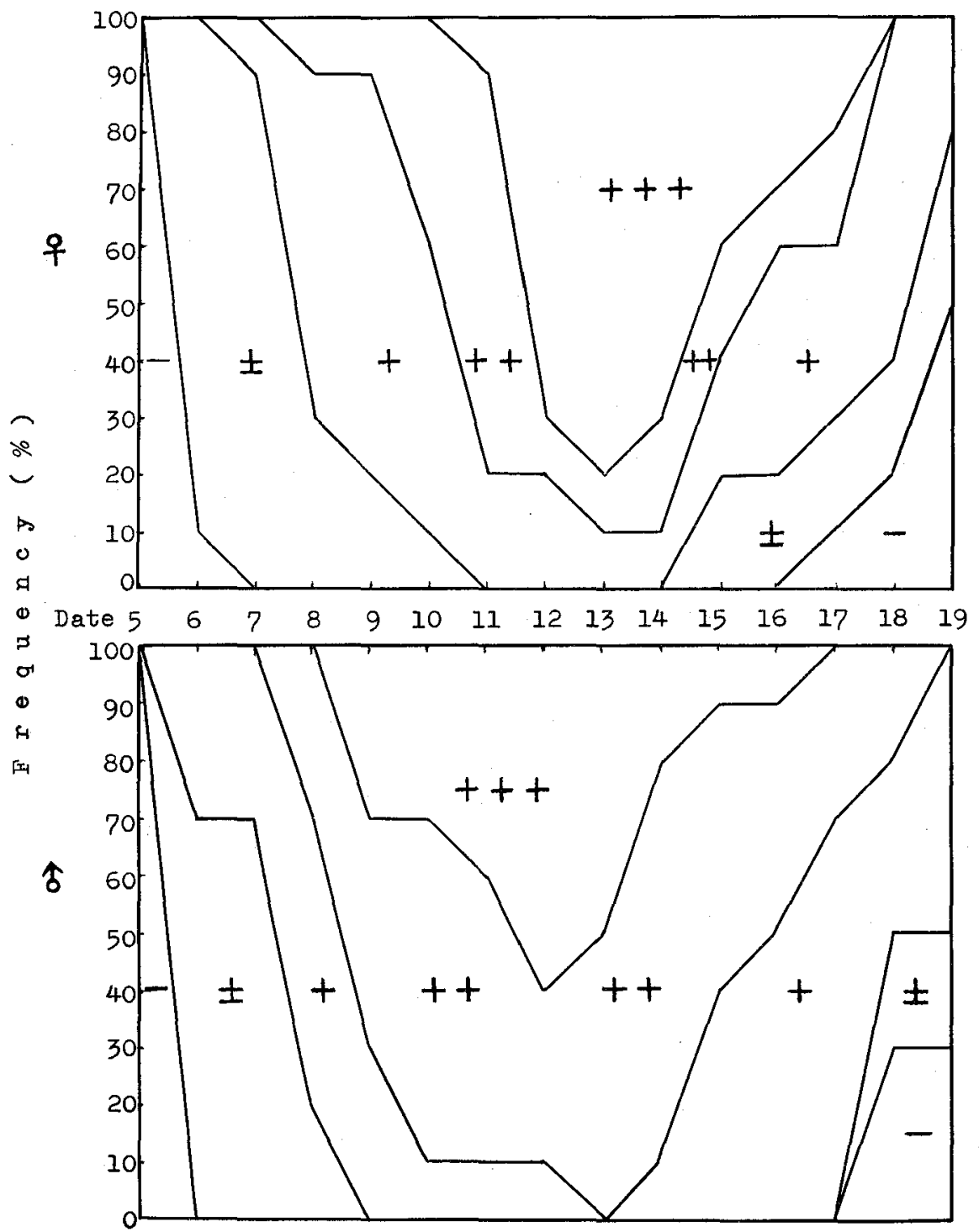

Text-fig. 3. Diagrams showing the percent frequency of individuals of respective maturation grades of the gonad in the pariod from July 5 to July 19,1961 .

Signs for maturation grades or classes...- : $<0.24 \mathrm{cc}$ of gonad volume in $ᄋ$ and $<0.24 \mathrm{cc}$ in $\hat{o}, \pm: 0.25-0.34 \mathrm{cc}$ in $ᄋ$ and $0.25-0.29 \mathrm{cc}$ in $\hat{\delta},+: 0.35-0.44 \mathrm{cc}$ in $\phi$ and $0.30-0.34 \mathrm{cc}$ in $\delta$, +1 : $0.45-0.54 \mathrm{cc}$ in $\phi$ and $0.35-0.39 \mathrm{cc}$ in $\delta$, H: $>0.55 \mathrm{cc}$ in $\%$ and $>0.40 \mathrm{cc}$ in $\delta$. 
granules in the lumen became smaller in size, but increased in number as though they were disintegrating. In the testis, tubules became thicker in diameter, spermatogonia in the germinal epithelium increased in number and there appeared cells in various stages of spermatogenesis. (Plate XIII, Fig. 7). Sperms were formed already. Groups of mature sperms gathered at the center of the lumen leaving a zone of spongy appearance between the central mass and the germinal epithelium. This stage roughly corresponds to the "Class 1" of Fox (loc. cit.), the "Stage 2-3" of YoshiDA and the "Stage II" in the growing gonads after FuJI.

On July 9. Gonads were in the class + in Table 1. Ovarian acinus highly increased in diameter and the wall became thin and hardly discernible (Plate XII, Fig. 3). There were many oocytes in various stage of maturation, but they were not yet filling up acinus; those in early stages were found next to the acinus wall. Any mature egg was not appaered yet. Larger oocytes attained already the size of fully mature egg, but the former were distinguishable from the latter by having a large germinal vesicle. Basophile granules disappeared from the acinus. In the testis, the tubules became thicker and so the germinal epithelium. Tubules were filled with cells in various stages of spermatogenesis and bundles of mature sperms gathered at the center. This stage corresponds to the "Stage 4" of Yoshida and the "Stage III" of pre-mature after Fujr.

On July 11. Gonads were in the class ++ in Table 1 . The acinus of ovary was almost filled with large oocytes and mature eggs each containing a small pronucleus instead of a large germinal vesicle (Plate XII, Fig. 4). Oogonia with a small nucleus were found scattering along the acinus wall. In a thin layer of cytoplasm along the acinus wall and in the substances filling the space among oocytes, small basophile granules appeared. Features of the testicular tubules were nearly the same as in the preceding stage, but the amount of sperms filling the central part of tubule increased (Plate XIII, Fig. 8). This stage corresponds to the "Class 2" of Fox, the "Stage 5 and 6" of Yoshida and the "Stage IV" of mature testis after FujI.

On July 13. Gonads were in the class +++ in Table 1. The acinus of ovary was greatly enlarged and interspace among acini became very narrow (Plate XIII, Fig. 5). Acini were filled with mature eggs and large oocytes, the former were more abundant than the latter. These cells were surrounded by a layer of homogeneous hyalin substance or jelly coat of a considerable thickness. In the tubules of the testis, cells in the spermatogenetic process decreased in number and thus the germinal epithelium became thinner, but the tubules were swallen with mature sperms (Plate XIII, Fig. 9). This stage of the gonads corresponds to the "Class 3" of Fox, the "Stage 7 and 8" of Yoshida and the "Stage IV" of FujI.

On July 15. The diameter of ovarian acini decreased remarkably and the wall became thicker. Mature and immature eggs were contained in acinus, but not so closely packed as in the previous stage and some of these eggs showed a sign of disintegration (Plate XII, Fig. 6). Basophile granules scattered in acinus increased in size. 
Oogonia scattering along the wall of acinus increased more or less in number. In the testis the amount of sperms in tubules decreased and the germinal epithelium became thinner, containing a small quantity of spermatocytes and spermatids beside spermatogonia lying close to the wall. The gonads were classified as ++ for their size and the amount of sexual products shed by the $\mathrm{KCl}$ method. However, the gonads differed from those observed on the 11 th in histological features and in the composition of eggs shed by forced spawning. Among eggs obtained in this way immature ones with germinal vesicle were not seldom on the 11 th, while over-ripe ones were contained together with immature ones on the 15th. This stage of the gonads on the 15th corresponds to the "Class 4" of Fox for spent, the "Atypical Stages 1-3" of Yoshida and the "Stage V" of FujI for spent.

On July 17. Goands were in the class + . Ovarian acini decreased in diameter and contained no mature egg at all. Sperms remaining in the testicular tubules were insignificant. Histological features of gonads much resembled those on the 9th. Sexual products obtained by forced spawning contained young oocytes and sperms were mostly inmotile. This stage of gonads corresponds to the "Class 5" of Fox and the "Stage 9" of Yoshida.

On July 19. Gonads were classified as \pm in Table 1. Ovarian acini became smaller and the wall thicker. Acini were not thorougly empty and there remained a few young oocyte in the lumen. Basophile granules of various sizes scatterecd on the surface of the thin germinal epithelium. In the testicular tubules sperms remaining in the lumen became fewer than on the 17 th.

\section{Maturation of gonads after spawning}

The results of the foregoing experiments 1-3 seem to suggest that the maturation rhythm of Mespilia followed the hemi-lunar periodicity at Seto and that one maturation cycle, i.e. from spent to spent, took about two weeks. However, it was questionable whether the wholly spent gonads could be full within a week. To answer the question the following experiment was carried out.

Sea urchins collected soon after the full moon of July 30, 1961, were kept in a water tank in the laboratory and the maturity was tested daily by random sampling. The grade of maturity was estimated by the methods used in previous experiments. The day in which most of specimens examined were nearly spent or spent was fixed as the initiation of the 8-day experiment. Of course there were individual variations in the maturity of gonads, but the variations were not great. The results of this ex-

Table 2. Maturation grade in 8 days after the spawning.

\begin{tabular}{l|ccccc}
\hline Day & 1 & 2 & 4 & 6 & 8 \\
\hline Mean maturity & \pm & \pm & + & ++ & +++ \\
\hline
\end{tabular}


periment are summarized in Table 2 which clearly showes that spent gonads matured in 7 or 8 days.

\section{Discussion}

With regard to the spawning periodicity of sea urchins there are two opinions contradicting with each other (reviewed by Harvey 1956). Fol (1879) stated that in Toxopneustes (= Paracentrotus) lividus and Spharechinus brevispinosus $(=S$. granularis) at Messina, the sexual products were liberated each month at full moon, and the animals were then empty for a few days. There are some evidences that Lytechinus ( $=$ Toxopneustes) variegatus at Beaufort is ripe at full moon and empty just after (Tennent 1910). In Lytechinus variegatus (Moore et al. 1963), spawning occurs throughout the summer season in Bermuda where it also exhibits a lunar rhythm related to full and new moon. The detailed study made by Fox (1924 a) shows that there is a lunar periodicity in the Red Sea form of Centrechinus (=Diadema) setosus at Suez. During the breeding season it spawns at full moon and becomes full again at the next full moon. But, no periodicity is found in the Mediterranean form of Paracentrotus lividus near Alexandria and either in this species at Naples, Marseilles and Roscoff. Fox's observations were not confirmed by MorTensen (1937) first, but in his later paper (1938) he admitted Fox's observations of a lunar periodicity in Diadema at Suez as a rare exceptional phenomenon. In Japan, Diadema setosum is distributed along the Pacific coast south of Bôsô peninsula, and Yoshida (1952) found some evidences to support Fox's view that the reproductive activity of this sea ruchin correlated with the moon age.

In contrast with these opinions, there are some workers who could not find any evidence of such a periodicity in sea urchins. LiLliE and JusT (1913) state that there is no evidence of periodicity in Arbacia puncturata. Koenler (1916), after examining a group of 20 specimens every five days for two months, stated that no regular variation both in size and in the gonad contents was found in Paracentrotus lividus at Naples. Tennent, Gardiner and Smith (1931) argue that evidences of lunar periodicity are not conclusive. Quite different from these opinions are the results of the present observations on Mespilia globulus at Seto; the spawning of eggs and the shedding of sperms take place not only at the full moon but also at the new moon, or the maturation rhythm in this species has a hemi-lunar periodicity. In this aspect, Mespilia globulus at Seto is similar to Lytechinus reported by Moore et al. (loc. cit.). Kume and DAN (1957) suggest that Diadema setosum spawns at the night of full moon in August and September at Misaki. The spawning of Mesiplia is not limited to a definite day or time of some day, but is made during a few days around the new and the full moon.

In relation to the spawning periodicity, the time necessary for maturation or the time necessary for the spent gonads becoming full of sexual products again has been 
discussed. According to Fox (1924 a), it takes about four weeks to obtain any ripe sperms or eggs in Diadema setosus at consecutive full moon at Suez. The time tis estimated from one and a half to two months in Paracentrotus lividus (KoEHLER 1916), two weeks in Lytechinus, Strongylocentrotus and Arbacia (TYLER 1949). About ten days in Strongylocentrotus purpuratus (Loeb 1915), nine days in Paracentrotus lividus (Fox 1924b) and a week in Lytechinus variegatus (Tennent 1910). Of these, KoemLer's (1916), Fox's (1924b) and TyLeR's (1949) observations are based on the results obtained by the window technique or the way cutting a window on the test to make the observations possible on live specimens. From the results of the present cxperiments, it is suggested that the recovery of gonads from spent to mature takes only 7 or 8 days in Mespilia. It is possible, therefore, that the same individual spawns twice a lunar month. Irrespectively of these evidences, it is still unknown how many times Mespilia spawns during its breeding season ranging from the middle of June to early September. As pointed out by Fox (1924 a), there remains a possibility that spent individuals will retire from the breeding place in shallow water to the deeper place and other mautre ones will appear in the breeding place in place of the spent.

The hemi-lunar periodicity of gonad maturation confirmed in the present work seems to be unique to Mespilia globulus at Seto, but the author's experiences seem to allude that it is commoh to some other kinds of sea urchins at Seto, such as Diadema setosum, Anthocidaris crassispina, Tripneustes gratilla and Hemicentrotus pulcherrimus.

The author wishes to express his thaks to the Director and the staff of the Seto Marine Biological Laboratory who gave him every facility for his researches at the laboratory. His thanks are also due to Professor Kenji Nakamura of the Kyoto University for his advices and valuable criticisms.

\section{Summary}

Mespilia globulus at Seto spawns twice a lunar month, once at the full moon and once at the new moon. Thus, the maturation rhythm of gonads harmonizes with the hemi-lunar periodicity. Recovery of both testis and ovary from spent to mature takes only a week. It is possible, therefore, that the same individual spawns twice a lunar month under natural conditions. The previous works on the spawning periodicity of sea urchins are discussed.

\section{REFERENCES}

FoL, H. 1879. Recherches sur la fécondation et le commencement de l'henogénie chez divers animaux. Mém. Soc. physique hist. nat. Genève Vol. 26: pp. 89-397.

Fox, H.M. 1924a. Lunar periodicity in reproduction. Proc. Roy. Soc. London B Vol. 95: pp. 523550 . 74 (=Biol. Rev.).

FujI, A. 1960. Studies on the biology of the sea urchin. I. Superficial and histological gonadal changes in gametogenic process of two sea urehin, Strongylocentrotus mudus and S. intermedius. Bull. Fac. Fish, Hokkaido Univ, Vol. 11 : pp. 1-14, 
Harvey, E.B. 1956. The American Arbacia and other sea urchins. Chapter 7: pp. 55-57. Princeton. Koefler, O. 1916. Uber die Ursachen der Variabilität bei Gattungs-bastarden von Echiniden. Zeits. Induk. Abstam. Vererbungs. Bd. 15: pp. 1-163: pp. 177-295.

Kume, M. and Dan, K. 1957. Collection of egg and sperm. Capter I. General remarks in Embryology of Invertebrate Animals (in Japanese, Ed. KuME, M. and DAN, K.). pp. 7-8. Baifukan, Tokyo.

Lewis, J.B. 1966. Growth and breeding in the tropical echinoid, Diadema antillarum philippi. Bull. Mar. Sci. Gulf and Carib. Vol. 16: pp. 151-158.

Lillie, F.R. and Just, E.E. 1913. Breeding habits of the heteronereis form of Nereis limbata at Woods Hole, Mass. Biol. Bull. Vol. 24: pp. 147-169.

Moore, H.B. 1934. A comparison of the biology of Echinus esculentus in different habitats. Part I. J. Marine Biol. Assoc. Vol. 19: pp. 869-881.

Moore, H.B., Jutare, T., Bauer, J.C. and Jones, J.A. 1963. The biology of Lytechinus variegatus. Bull. Mar. Sci. Gulf and Carib. Vol. 13: pp. 23-53.

Mortensen, Th. 1937. Contributions to the study of the development and larval forms of Echinoderms. III. Kgl. Dansk. Vidensk. Selsk. Skr. Naturv. Math. Ser. 9, Vol. 7, No. I.

1938. Contributions to the study of the development and larval forms of Echinoderms. IV. Ibid. Vol. 7, No. 3.

Tennent, D.H. 1910. Variation in Echinoid plutei. J. Exp. Zool. Vol. 9: pp. 657-714.

Tennent, D.H., Gardiner, M.S. and Sмith, D.E. 1931. A cytological and biochemical study of the ovaries of the sea urchin Echinometra lucunter. Tortugas Lab., Vol. 27 and Carnegie Inst. Washington, Pub. No. 413: pp. 1-46.

Tennent, D.H. and Ito, T. 1941. A study of the oogenisis of Mespilia globulus (Linné). J. Morph. Vol. 69: pp. 347-404.

TYLER, A. 1949. A simple non-injurious method for inducing repeated spawning of sea urchins and sand dollars. The collecting Net Vol. 19: pp. 19-20.

Yoshida, M. 1952.,Some observations on the maturation of the sea-urchin, Diadema setosum. Ann. Zool. Jap. Vol. 25: pp. 265-271.

\section{EXPLANATION OF PLATES XII AND XIII}

Plate XII; Grade of maturation of the ovary.

Fig. 1. on July 5, Class -.

Fig. 2. on July 7, Class \pm .

Fig. 3. on July 9, Class + .
Fig. 4. on July 11, Class \#.

Fig. 5. on July 13, Class H.

Fig. 6. on July 15, Class H.

Plate XIII; Grade of maturabtion of the testis.

Fig. 7. on July 7, Class \pm .

Fig. 9. on July 13, Class H.

Fig. 8. on July 11, Class H. 
Publ. Seto Mar. Biol. Lab., XIV (5), $1967 . \quad$ PlATE XII

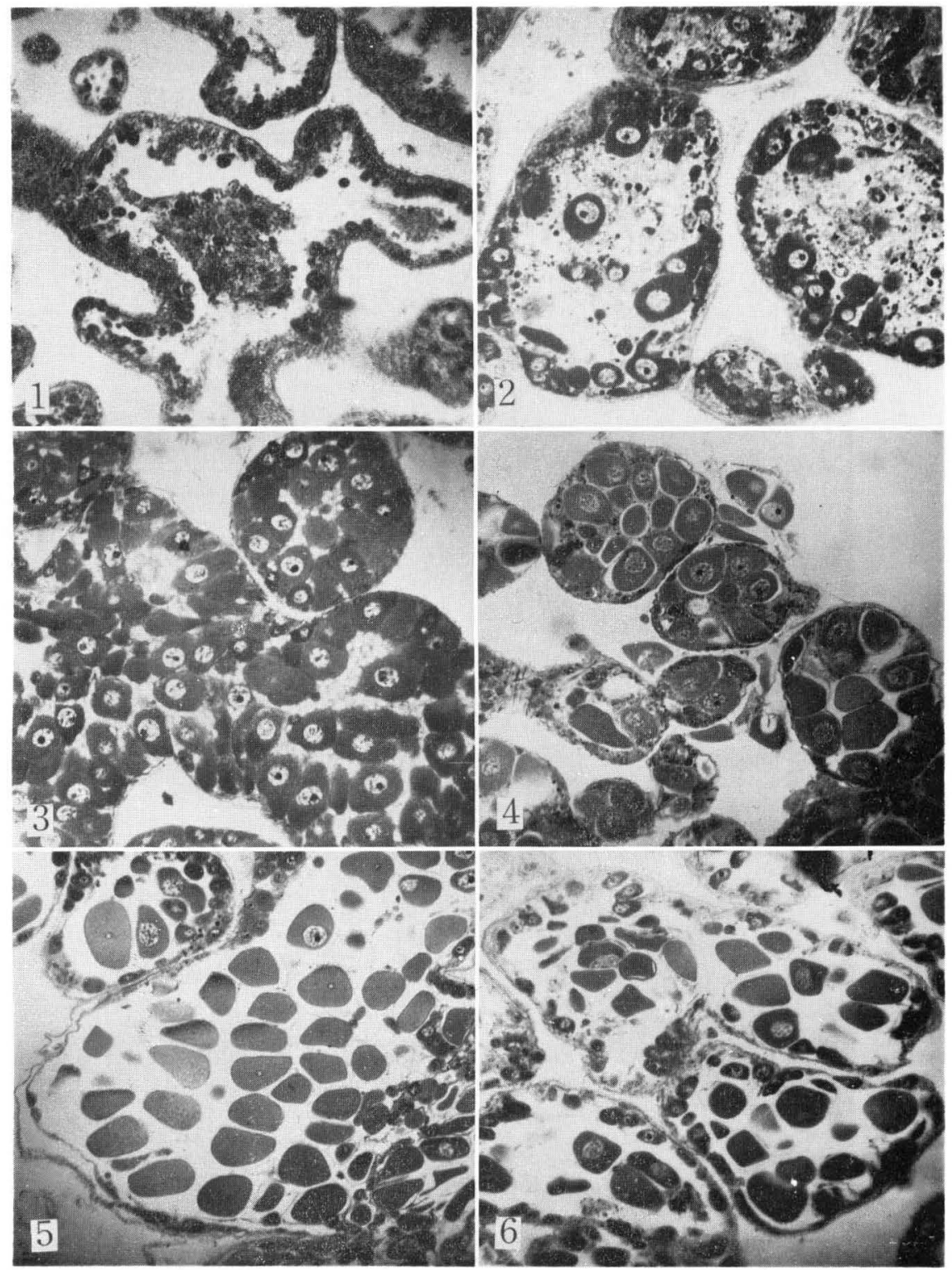

N. Kobayashi: Spawning Periodicity of Sea Urchins, I 
Publ. Seto Mar. Biol. Lab.. XIV (5), $1967 . \quad$ PlATE XIII

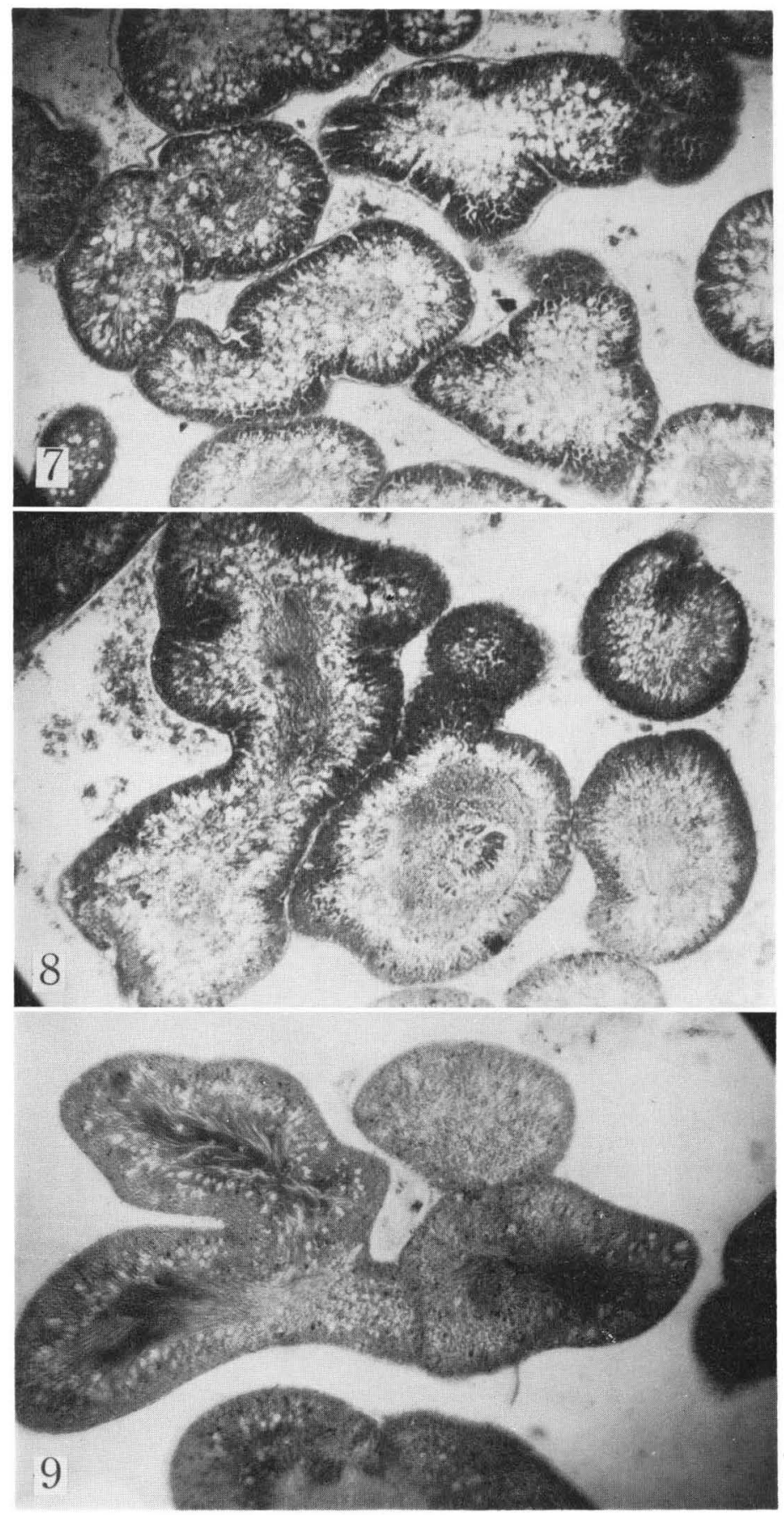

N. Kobayashi: Spazening Periodicity of Sea Urchins, I 